\title{
The city as a theatre of characters. John Hejduk's Masques
}

\section{La ciudad como teatro de personajes. Las Masques de John Hejduk}

\section{Luca Cardani}

School of Architecture, Urban Planning, Construction engineering. Politecnico di Milano. Italy.

luca.cardani@polimi.it 


\begin{abstract}
The architectural work of John Hejduk (1929-2000) is marked by theoretical-design research, collected in series with titles and periods. Among these series the one entitled Masques, developed since about 1979 , can be considered the nucleus of his research on the architecture of the city and the place of origin of his language of construction later developed in his realized buildings. This paper analyses the dense network of references and analogies established by Hejduk to create his Masques, trying to fix its origin in the idea of the city as a theatre of characters composed of architecture. Starting from the name chosen for the title of this series, the paper tries to trace the threads that lead from the general work of the various projects of the Masques series, to the reflections and ideas that produced it. Then, it comes back again to the ob-servation of architecture and of a case study (Security, 1989), to understand and explain its meaning and the compositional methods involved into the process of genesis of form. Through the entire work named Masques, and its recognizable link with the buildings and installation realized around the world, Hejduk has built an archive of architectural prototypes ready to construct different parts of the city, thus highlighting the strong connection that his work establishes with reality in order "to conceive it, represent it and finally realize it".
\end{abstract}

\title{
Key words: Hejduk; Masques; architecture; characters; collage
}

\section{Resumen}

La obra arquitectónica de John Hejduk (1929-2000) está marcada por la investigación teórica y de diseño, recogida en series con títulos y períodos diferentes. Entre estas series, la titulada Masques, desarrollada a partir de 1979, puede considerarse el núcleo de su investigación sobre la arquitectura de la ciudad y el lugar de origen de su lenguaje constructivo desarrollado posteriormente en los edificios realizados. Este artículo analiza la densa red de referencias y analogías establecidas por Hejduk para crear sus Masques, tratando de fijar su origen en la idea de la ciudad como un teatro de personajes compuesto por la arquitectura. Partiendo del nombre elegido para dar título a esta serie, el artículo intenta trazar los hilos que conducen desde el trabajo general de los distintos proyectos de la serie Masques, hasta las reflexiones e ideas que la produjeron. A continuación, vuelve de nuevo a la observación de la arquitectura y a un estudio de caso (Security, 1989), para comprender y explicar su significado y los métodos compositivos que intervienen en el proceso de génesis de la forma. A través de toda la obra denominada Masques, y de su reconocible conexión con edificios e instalaciones realizados en todo el mundo, Hejduk ha construido un archivo de prototipos arquitectónicos listos para construir diferentes partes de la ciudad, poniendo así de manifiesto la fuerte conexión que su obra establece con la realidad para "concebirla, representarla y finalmente realizarla".

\section{Palabras clave: Hejduk; Masques; arquitectura; personajes; collage}

\section{Para citar este artículo / To cite this article:}

CARDANI, L. La ciudad como teatro de personajes. El Masque de John Hejduk. En:[i2] Investigación e Innovación en Arquitectura y Territorio [en línea]. 2021, Vol. 10, Núm. 2, pp. 51-74. ISSN: 2341-0515.

https://doi.org/10.14198/I2.17415

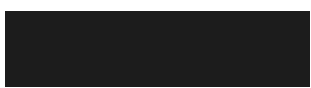




\section{Introduction}

John Hejduk's work is generally divided into phases and periods ${ }^{1}$ reflecting his theoretical and design research, which addresses certain issues over a period of time until fixing their conclusions through architectural experiments.

This serial work corresponds to a continuous and progressive research into the means and ends of architecture ${ }^{2}$, culminating in a poetic vision that encompasses the artistic, philosophical, and social aspects of the discipline.

In particular, the series entitled “Masques”, developed approximatively since $1979^{3}$, gathers a various number of projects, representing the core of his research on the architecture of the city and the genesis of his language of construction ${ }^{4}$.

These projects are mainly narrated by their author with extremely refined art books ${ }^{5}$ where his work is presented with an extensive set of drawings of different graphic nature (watercolour, sketches, technical drawings, urban plans, collages), accompanied by descriptive texts, short stories, quotations and above all by poems, which constitute a complete language of Hejduk's work 6 . (Fig.1)

${ }^{1}$ This cataloguing is suggested by the same Hejduk who has clearly enunciated it in his monograph: «Only in conscious retrospect does it become clear that a body of work is in fact a product of the time it was fabricated in. (...) The work in this book ranges over 36 years, falling into distinct dates (time) produced in particular cities (places). The production is framed in time, each frame providing a field for working within. The first frame fixes the years $1947-1954$, school years in New York, Cincinnati, Boston and Rome. The second frame 1954 - 1963 covers Texas, New York, Ithaca and New Haven. The third frame 1963 - 1967, Cooper Union and New York. The fourth frame 1968 - 1974, the Bronx. The fifth frame 1974 - 1979, Venice. The sixth frame, Poems. The seventh frame, 1979 - 1983, Masques: New York-Berlin.» Cfr. HEJDUK, J. Aspects of Segments, In: HEJDUK, J. Mask of Medusa. Works 1947-1983. New York: Rizzoli, 1985. p.23

${ }^{2}$ About the sense of unity and continuity of Hejduk's work. Cfr. ZULIANI, G. End Games - Notes about John Hejduk's Architecture. In: FAMagazine. 2014, September-October, no. 29, pp. 48-60

${ }^{3}$ «Wall: The Masques/Masks date from 1979; Hejduk: Yes. (...)». Cfr. Op.Cit. HEJDUK, J. Mask of ... pp.127-128

${ }^{4}$ Following the cataloguing system of "John Hejduk Collection" held at the CCA of Montreal, it is possible to list as "Masques" series the following projects: Lancaster/Hanover Masque 1979-83, Berlin Masque 1981, Victims I 1984, Chicago Fair 1984, Riga 1985, Vladivostok 1983-87, Lake Baikal 1985, Bovisa 1987-1990.

${ }^{5}$ HEJDUK, J. Mask of Medusa. Works 1947-1983. New York: Rizzoli, 1985; HEJDUK, J. Victims. London: Architectural Association, 1986; HEJDUK, J. The Collapse of Time. London: Architectural Association, 1986; HEJDUK, J. Bovisa. Rizzoli and Harvard University Graduate School of Design, 1987; HEJDUK, J. Vladivostok. New York: Rizzoli, 1989; HEJDUK, J. The Riga Project, Philadelphia: University of Arts, 1989.

${ }^{6}$ RIZZI,R. John Hejduk. Incarnatio. Venezia: Marsilio, 2010. Cfr. «Il cosmo del pensiero hejdukiano è sempre "realtà" unitaria, indivisa: forma trinitaria costituita da poesia, pittura, progetto. Sono mondi interconnessi, indisgiungibili, inseparabili, gerarchicamente disposti come gli ordini angelici, per colmare distanze altrimenti incolmabili. Quelle comprese tra universalità e particolarità, tra contemplazione e compassione». p.20 
This multifarious storytelling composed with a various range of languages reflects the nature of John Hejduk Masques, developed thanks to an analogical thought, that links together in the project different forms of knowledge, translating his thought into architecture, as he noticed: "Art, be it painting, literature or architecture, is the remaining shell of thought. Actual thought is of no substance. We cannot actually see thought, we can only see its remains. Thought manifest itself by its shucking or shedding of itself; it is beyond its confinement ${ }^{7}$.

Starting from the large apparatus of essays and scripts about John Hejduk Masques ${ }^{8}$, this paper specifically aims to enlighten the conceptual core of this thought about the role of architecture in the representation of the city and society and the consequences it plays on Hejduk's architectural composition and language.

In order to understand this idea and its results it is necessary to reconstruct the deep network of analogies that nourishes Hejduk's design reflection, starting from the reference which gives the name to the series: the Masque.

\section{The city as a theatre: a conceptual and formal analogy}

The origin of the title Masque could be found in a reference to the theatrical form developed at the English Stuart Court during the $16^{\text {th }}$ and especially the $17^{\text {th }}$ century 9 . (Fig.2)

The Masqueswere private theatre productions for a small audience partly involved in the action, held in the hall of noble mansions and mostly during the banquets at the Whitehall Palace. In fact, the plot generally tells an allegorical story that establishes numerous analogies with the people to whom the performance was dedicated (sovereigns, men of the court), or the occasion celebrated, thus narrating in parallel an idealistic life of the society and the city.

${ }^{7}$ HEJDUK,J. Evening in Llano. In: HEJDUK, J. HENDERSON, R. Education of an architect: The Irwin S. Chanin School of
architecture of the Cooper Union. Edited by: DILLER, E. LEWIS, D. SHKAPICH, K. New York: Rizzoli, 1988.

${ }^{8}$ VAN DEN BERGH, W. John Hejduk's Masques. In: Forum. 1988, May, no. 02, pp. 32-41; CHIN, L. The Problem with Architect as Writer...: Time and Narrative in the Work of Aldo Rossi and John Hejduk. In: Architecture, Ethics and Technology, edited by PELLETIER, L. and PÉREZ-GÓMEZ, A. McGill-Queen's University Press, 1994, pp. 199-221; BARBERÀ PASTOR, C. De la Widow's Walk a Security. Una interpetración sobre Las Masques de John Hejduk. In: Proyecto, Progreso, Arquitectura. 2018, Noviembre, no.19, pp. 84-97.

${ }^{9}$ BROCKETT, O.G. Storia del teatro. Italian Edition by: VICENTINI, C. Venezia: Marsilio editori, 1988. pp. 210-213. Cfr: «The masques, which were in vogue at the court of Henry VIII, were rarely performed during Elizabeth's reign. But when James I came to the throne, the staging of the masques was resumed with particular splendor. (...) Enormous sums of money were allocated for the staging of these productions. (...) Most of the masques presented at the court of the Stuarts were written by Ben Johnson while the sets were designed by Inigo Jones. (...) The masques had some traits in common with the Italian intermezzi. In both, an allegorical story was told that highlighted numerous analogies between the person to whom the show was dedicated, or the occasion that was celebrated, and certain characters or mythological episodes. The story and allegorical references were expressed mainly in visual forms: through the scenes, costumes, objects, mimicry and dance. The story and dialogue, spoken or sung, were used to illustrate what could not be communicated through visual language.» pp. 210-211 (Author Translation) 
The allegorical references and metaphors are expressed in visual forms through costumes, mimicry, dance and above all through the spectacular mechanised staging of the halls, usually realized by Inigo Jones (1573-1652), who is specifically mentioned by Hejduk: "(The Masques were) fabulous because not only was Inigo Jones interested in doing the masque but also what's behind the masque... Jones had the illusionary aspect of what was on stage. ... He built all systems, systems of thought.»10.

In Hejduk's writings the reference to English Masque is often mentioned but never fully explained, using the term in an allusive and extensive manner, to encourage a multiplication of imaginary connections.

We can assume as a starting point that the reference is used to express the great analogy established between the city and the theatre that provides the pretext for these projects. The city can be compared to theatre because both are forms of representation of the life of society, each with its own structure and language.

In particular, for Hejduk theatre gives structure and rules to society as a form of interpretation of its own time, as he states: "Masque is theater and ritual theater has been intimately related to the historic regulation of the social structure. Theater is a manifestation, which is capable of keeping society balanced, and that is the point of communitas. In theater we can begin to undertake an investigation of the phenomena on which our present society rests. $»^{11}$

In this theatre, each actor has a role in relation to a plot and a ritual action, that is fixed by repetition in the time and space of the scene, staging a representation of life, in which the spectators recognize the structure and dynamics of society.

Therefore, the representation of masques has a critical role about reality, as the historian Oscar Brockett notices considering one of the major writers of English masques Ben Johnson (1572-1637) "In these works, which expose the weaknesses of contemporary 'types', Johnson's main concern is to correct human behaviour. His works are often referred to as "realistic" and "corrective" because the characters appearing in them, on the one hand, seem to arise from direct observation of reality and, on the other, always end up being punished for their faults. ${ }^{12}$

\footnotetext{
${ }^{10}$ J.HEJDUK \& D.SHAPHIRO, Conversation between John Hejduk and David Shaphiro “The Architect Who Drew Angels". In: $A+U .1991,01$, no. 244, p.61

${ }^{11}$ HEJDUK, J. MASQUES, John Hejduk. Edited by SCHULZE, F. Chicago: The Renaissance Society at The University of Chicago, 1981.

${ }^{12}$ (Author Translation) Cfr. Op.Cit. BROCKETT, O.G. Storia del teatro... pp.184-185
} 
For Hejduk Masques projects have similar a refounding value as he expresses in the introduction and conclusion of the series: «So completes the masque, which in a way composes a masque of our time. As it was necessary for the highly rational-pragmatic city of 15 th century Venice to create masques, masks, masses for its time in order to function; it would appear that we must create masques (programs) for our times» ${ }^{13}$.

The creation of architectural masques and masks of his own time means finding the distinctive values of one's own era and translating them into the language of architecture, whose task is expressing an idea of society in which people can recognise themselves. That means that only the reflection on the authenticity of architectural programs of his own age allows to develop an authentic and new architecture $^{14}$.

This need and desire to update the idea of living in his age, to refound the meaning of each building in relation to the sense of the city and society, reveals the conceptual origin of Hejduk's Masque: an idea of city-theatre that allows him to release his architectural language, as a personal way of rethinking the authenticity of the relationship between man and architecture.

However, the analogy between the city and the theatre extends to broader horizons, affecting the architectural composition techniques used to represent it.

Masque recalls the idea of 'masquerade', as the parade of character and effects uses to express the life and roles of society, that builds, between the $15^{\text {th }}$ and the $17^{\text {th }}$ European Theatre, the scenic space of the festival, both in the private theatre and in the public one.

In the English Masques, the sets and characters with masks and costumes fix the general character of the narrative, in which the action takes place. Similarly, Hejduk's Masque represents the ideas and characters that populate the city, realizing urban scenes and actions, through a set of architectures, a company of buildings as a cast of actors. (Fig.3)

"I have established a repertoire of objects/subjects and the troupe accompanies me from city to city, from place to place, to cities I have been to and to cities I have never visited. The cast presents itself to a city and its inhabitants. Some of the objects are built and remain in the city; some are built for a time, then are dismantled and disappear; some are built, dismantled and move on to another city where they are reconstructed.»15

\footnotetext{
${ }^{13}$ HEJDUK, J. Riga, Vladivostok, Lake Baikal / a work by John Hejduk. Edited by SHKAPICH, K. New York: Rizzoli international, 1989. p.15

${ }^{14}$ «I pondered this acr a long time and I came to the understanding that a deep search into the "nature" of program might perhaps be attempted... a search towards the possibility of a renewal... a program that perhaps had something to do with the "spirit of our times". It is with the above in mind that I submit a Berlin Masque». En: HEJDUK, J. with PALESTRI, G. Berlin Masque. Design fo Block 19, Südliche Friedrichstadt. In: Lotus International. 1981, no.33, pp.2125

${ }^{15}$ Op.cit. HEJDUK, J. Riga, Vladivostok, Lake Baikal... p.15
} 
In architectural terms, the result is an idea of the city as an addition of individual architectures, that give shape to the programs of society, transforming them into characters; and these characters related one to each other, according to certain hierarchies, build the character of the city as a composition of architectures.

The reference to the theatre therefore concerns the poetics of the narration of this city.

Hejduk seems to recover from the history of $15^{\text {th }}$ century public theatre, such as the floats of the English 'street peagents' and the Italian 'Ingegni"16, the idea of the city as a fixed scene, where, on a backdrop of real architectures, a series of places for action are superimposed with a paratactic structure, composed by fixed areas dedicated to representation and itinerant structures, each of them "is a scene, a theatrical space in itself and a qualifying part of the theatrical space of the city ${ }^{17}$.

The architectural translation of this analogy is a city as a scenic space: the place of the action of the characters of the urban drama, which following the analogical path are the architectures with their character.

Some of these architectures have a fixed character, establishing hierarchies between places, where some wandering architectures can find their place. These "nomadic architectures" 18 - just like in the history of urban theatre - moving and approaching the places depicted in the background of the city as a fixed scene, build different atmospheres, situations and meanings. (Fig.4)

\section{Mask and Character: Architectures as Characters}

The direct consequence of the conception of the city as a theatre of characters is the focus of design reflection on the individual definition of architecture, on the role of each building in the city.

The reference to the theatrical Masque introduces the theme of the character and his mask.

Hejduk establishes one other analogy between theatre and the city, so just as in theatre masks make the characters of society evident, architecture is entrusted with the task of manifesting the characters that build the city, and thus the narration of its meaning.

\footnotetext{
${ }^{16}$ In Europe during the 14th and 15th the public street theatre increased. Spaces of the quotidian life of city were transformed into artificial spaces for the theatre, reorganized for the representation. «The theater is now explained as a "public space", solemn space. And the two poles of the scenic space are the solemn and public place and the place deputed in action ("Ingegni") in the dialectic between transformed city spaces and community scenic spaces. The tension towards the formal definition of the scenic place and the place for the performance, in the complexity and multiplicity of performances, spaces and scenes, is inscribed here.» (Author Translation) Cfr. CRUCIANI, F. Lo Spazio del Teatro. Bari: Editori Laterza, 1992, p.56

${ }^{17}$ Ivi. p.53. (Author Translation) Cfr. «ognuno è scena, spazio teatrale in sé e parte qualificante lo spazio teatralizzato della città»

${ }^{18}$ VIDLER, A. The Architectural Uncanny. Essays in the Modern Unhomely. Cambridge - London: MIT, 1992.
} 
This conception forces the design process on the fundamental problem of the identity of each architecture: what a character/architecture is, what is its role in the whole scene/city and what is its representative mask/form, or rather the character of the building.

It means an a priori reflection on the types of architecture that compose the structure of the city, whose origin is fixed before their genesis.

For this reason, Hejduk's Masque generates new programs and new architectural forms, because it stimulates a continuous questioning about the identity of architecture, what things are and what they represent.

So, both Theatre Masque and Hejduk's architectural one focus on the topic of character, giving formal representation to the characters/architectures and their role in the city, thus providing a fixed definition to each of them.

This aim recalls ideas of "architecture parlante"19 of the so-called revolutionary architects ${ }^{20}$, for which the building must show with its features the function for which it was built and have an effect on the viewer's soul, in accordance with the feeling to be evoked. In this sense, Hejduk's work recalls Claude Nicolas Leodux's ideal city of the Salines de Chaux, for the same desire to make explicit the relationship between architecture and the lives of the inhabitants and the sense of the city as a real representation of this connection.

Even in terms of project design, they are quite similar, thinking to the words from Ledoux's Treatise: "La variété donne à chaque édifice la physionomie qui lui est propre»"

In fact, Hejduk starting from an architectural genre, that can be the house, the workplace or the public building, gives a specification, an activity, a craft, which individualizes the character of the building. Each building/object of the masque is therefore named and corresponds to one inhabitant/subject. the widow's house / the widow, the solicitor's office / the lawyer, the church house / the priest, the animal hospital / the veterinarian, etc...

Each couple of object/subject is then accompanied by a small canovaccio describing the activity that takes place, thus revealing the conceptual core of the formal procedure: the ritual as the link between life and architecture, between the world of form and that of function, the interpretation of which is the core of the genesis of form. (Fig. 5)

\footnotetext{
${ }^{19}$ The definition is mentioned by Emil Kaufmann, referring to an anonymous critical essay about Ledoux's Work published in 1852. Cfr. KAUFMANN, E. Three Revolutionary Architects: Boullée, Ledoux, and Lequeu. American Philosophical Society, 1952, p.447. For a current use definition: «Architecture expressive of its purpose by means of its form, a term first used by print by L.Vaudoyer in respect of the French 18th notably Ledoux». Cfr. CURL, J.S. A dictionary of Architecture and landscape Architecture, 2000.

${ }^{20}$ KAUFMANN, E. Tre architetti rivoluzionari. Boullée, Ledoux, Lequeu. Milano: Franco Angeli, 1976.

${ }^{21}$ LEDOUX, C.N. L'architecture considérée sous le rapport de l'art, des moeurs et de la législation. Paris: 1804, p.10.
} 
Rafael Moneo points out about: "(...) "Form implies function". The world of forms in which John Hejduk operates precedes function: the architect is the mediator capable of giving forms - and naturally not only geometrical forms - their most appropriate use ${ }^{22}$ So for Hejduk forms need to be always linked to life, and they are not beautiful in themselves but only when referred to their content.

The search for the formal expression of the link between architecture and its inhabitant, or, following the analogy, between the mask and its character, leads Hejduk to one of his most surprising discoveries, extending the field of the character of the building to a resonance to its inhabitant.

Just as the mask expresses not only the social role but also the state of mind of his character, architecture can take charge of telling the biographical and psychological aspects of the inhabitant: "a piece capable of expressing and transmitting the sensation of the people who occupy its interior... The masques will be the expression of its in habitants» ${ }^{23}$.

Definitively, architecture as characters: it is this further metaphor among others of the great allegory of the Masques that leads Hejduk to establish a formal analogy of his architecture with the world of human or animal figures, seeking to evoke particular meanings or qualities of the inhabitants through the architectural personification and the rhetorical figure of 'prosopopoeia', which derives from the Greek compound poiéo "to make" and prósōsopon"face" and so again recalling the mask.

\section{4. "Security": an architectural mask}

For example, a figure of Hejduk's "cast"called Security ${ }^{24}$ re-appears in various Masques: a small building represents the character of security, a mask inhabited by the security man.

This character/architecture was finally built by the students of the Oslo School of Architecture in $1989^{25}$ as a temporary inhabitable installation, thus providing a tangible vision of the architectural relevance of the Masque's characters.

Security is the result of the assembly of architectural elements: 4 pillars, a cubic room, a staircase, a wall and a cantilevered loggia or pulpit. These elements build a quadruped figure 10 meters high with a tail for ascent at the back and a wall suspended at the front, connected by a room of minimal dimensions raised on 4 legs (Fig.6)

\footnotetext{
${ }^{22}$ MONEO, R. Ciphered Messages. In: HEJDUK, J. Bovisa. New York: Rizzoli, 1988, (no numbered pages)

${ }^{23}$ BARBERÁ PASTOR, C. From the Widow's Walk to Security: an Interpretation on the Masques of John Hejduk., In: Proyecto, Progreso, Arquitectura, n.19, Noviembre, 2018. p. 89.
${ }^{24}$ This character appears in several masques: "Lancaster/Hanover Masque" the project for a community foundation city started in 1979; "Chicago Fair" 1984, "Victims" for Berlin in 1984, "Vladivostok" 1987; and later in "Pewter Wings, Golden Horn, Stone Veils" 1997.
${ }^{25}$ CONRAD, M. THÅN, A. Security: a work by John Hejduk. Oslo: Aventura Forlag, 1995.


The cubic cell is a room for the rest, the home of the man who exercises security: a room raised from the ground that has no relationship with the city, in which the only openings are 15 triangular-section tubes inclined at 45 degrees to the rear, which allow light to illuminate the room, characterizing the crowning. The introverted character is then accentuated by two sharp lances protruding from the sides, keeping a distance from the building.

A square wall juxtaposed and attached with a slender passage to the cell is the element that connects the inhabitant with the city, through a threshold. On the wall, just like a square 'ruff' ${ }^{26}$ or 'gorget' ${ }^{27}$, a head appears, a cantilevered loggia clinging to the wall, isolated like the face in the seventeenth-century collar, to put the inhabitant in relation with the city through the gaze.

This unit placed upon the centre of the wall like a cyclopean eye observes anyone who passes from an elevated position, intimidating the inhabitants; the building has legs and wheels that allow it to move from place to place, pulled by the population, controlling the entire Masque area.

By placing itself in Christiania Torv, the 17 th century Town Hall square in Oslo, it changes the architectural meaning of the square itself with its presence. By taking a specific position diagonally with respect to the regularity of the square, it gives a different hierarchy to the architectural facades and the access roads, and by moving inside along this new axis it can modify constantly the perception of the space.

Speaking about the history of this square, also related to nazi occupation, Carlos Barberà Pastor recently has noticed: «Upon taking possession of the place, the awakening of memories that had to do with social and collective responsibility where architecture acquires a commitment was felt. The mere presence of the piece, its construction in the plaza modified the public space. The architectural intention was present and expressed a feeling that, often only manifests itself in ideas or event. Through Security, it is proposed as an expression by itself. ${ }^{28}$

Its physical presence carried around by citizens shows that the origin of the feeling of security lies in the idea of collective living rather than in the imposition of an instrument of control over people.

\footnotetext{
${ }^{26}$ Ruff:countabale noun; 1 . A ruff is a stiff strip of cloth or other material with many small folds in it, which some people wore round their neck in former times. In: Collins English Dictionary. HarperCollins Publishers.

${ }^{27}$ Gorget: noun; 1. a collar-like piece of armour worn to protect the throat; 2. a part of a wimple worn by women to cover the throat and chest, esp in the 14th century. From the old French, gorge. In: Collins English Dictionary. HarperCollins Publishers.

${ }^{28}$ Op.Cit. BARBERÀ PASTOR, From the widows'... p. 96
} 
In this sense, therefore, the location in the place of origin of the city of Oslo, where King Christian IV decided to rebuild the city after the fire in 1624 with the new government building, reinforces and communicates the refounding spirit of the Masque's programs above mentioned and the necessary connection between architecture and community life.

\section{Composition and collage}

Looking at the compositional process of Security, but also of the other characters of the Masqueseries, it is possible to explore one other reference that help to frame the process of Hejduk's work.

Speaking about the gestation of each character of his Masque Hejduk recalls Pablo Picasso's wooden masks ${ }^{29}$, revealing some aspects related to the genesis of the form and the compositional technique involved in Masque's project. (Fig.7)

An aspect lies in a strong use of imagination during the compositional process thanks to an analogical thought that allows to create new form and meanings evoking and mixing together figures from different formal worlds.

Picasso's masks are in fact made up of objects taken from everyday life, geometric figures, scrap and anything else recognized by the painter's imagination, capable of stimulating a new association of meanings connected to the theme developed through the artwork.

Just as in Picasso's work, in the architecture of Hejduk's Masque, the elements of the composition are elementary and familiar objects with a simple geometry, but connected in such a way that they arouse in the observer a reference to other worlds, to other figures.

This process can be also connected to Le Corbusier's objet a reaction poetique, one of the architects investigated by Hejduk, where the analogy with the formal worlds of nature and technology triggers the discovery of the new form.

In his article "Out of time and into space", published for the first time in 1965 on L'Architecture d'aujourd'hui ${ }^{30}$, Hejduk affirms that in Le Corbusier's work the "revolution of Cubist space in architecture" ${ }^{31}$ happened, introducing the issues of Cubist painting into architectural composition.

\footnotetext{
${ }^{29}$ HEJDUK, J. Vladivostok. New York: Rizzoli, 1989. p.100

${ }^{30}$ HEJDUK, J. Hors du temps dans l'espace. En: L'Architecture d'aujourd'hui. 1965, septembre-novembre, no. 122, pp. XXI et XXIII; HEJDUK, J. Out of Time and Into Space. In: Op.cit. HEJDUK, J. Mask of Medusa... pp.71-75

${ }^{31}$ HEJDUK, J. Out of Time and Into Space. In: Op.cit. HEJDUK, J. Mask of Medusa... p.71
} 
In the Cite de Refugé for example Hejduk observes that the problem of the "Centralized relief upon a tableau"32 of Cubism paintings, that means the relationship established between a central figure emerging from a structural background plane, is expressed by the relationship between plastic and technical forms: "One might infer that Le Corbusier was manipulating two major compositional themes; that is, the play between the biomorphic and the biotechnic. The predisposition towards the biomorphic in the entry pavilions and towards the biotechnic in the gridded glazed, and evenly modulated tableau-facade. The juxtaposition of these two themes represents a particular condition of modern architecture: one, the technological precision of the high-rise tableau-facade and two, the spatially oriented pavilions placed near the grade and near to man. It became apparent that several of the Cubists, in particular Gris and Léger operated within similar field of ideass ${ }^{33}$.

It is possible to speculate that in this article resides the seed of one of the Masque's greatest discoveries, namely the possibility of relating explicitly through architectural composition the forms of construction with those of figuration.

Thinking about Security project it is interesting to notice some compositional and figurative aspects that recall Le Corbusier's works, like Convent of Sainte-Marie de la Tourette (1953-1960).

The cubic volume of the room of Security is raised off the ground to gain autonomy, like Le Corbusier's Prayer Room floating inside the cloister on top a cross-shaped bearing wall. In addition, in both cases the shape of the roof is used to reinforce the specific character of the building, creating surprising lighting effects in the interior. Another connection could be found on the back-front of the church where the volume of the organ cantilevered on a nude wall seems to reappear in Security's façade, transformed in a figure, evoking with a climax towards the centre of the wall the same upsetting feeling.

These aspects are exalted in Hejduk's work and led to a conception of architecture as "body and/or machine" ${ }^{34}$, where the re-composition of references to other formal worlds feeds the work with different degrees of meaning. (Fig.8)

As a consequence of this strong use of analogies, the design process is marked by collage as the technique more akin to the mental process involved, in which it is possible to find a way of interpreting some topics of Aldo Rossi's analogous architecture ${ }^{35}$.

\footnotetext{
${ }^{32}$ Op.Cit. HEJDUK, J. Mask of Medusa... p.66

${ }^{33}$ Ibidem

${ }^{34}$ SEMERANI, L. Lama \& Ingranaggio. In: Incontri e Lezioni. Attrazione e contrasto tra le forme. TECA 8 Teorie della Composizione Architettonica. Napoli: CLEAN. 2013. pp.158-167

${ }^{35}$ CARDANI, L. John Hejduk vis-à-vis Aldo Rossi. In: Aldo Rossi, PERSPECTIVES FROM THE WORLD. Theory, Teaching, Design \& Legacy. edited by BOVATI, M. CAJA, M. LANDSBERGER, M. LORENZI, A. Padova: IL Poligrafo, 2020. pp. 218225.
} 
For both collage and assemblybecome the way to express in the composition not only the meanings of references but a sense of the form that includes and expands them into a more extended meaning: "Collage evidently designates a technique but also a state of mind in the face of artistic creation:pre-existing elements, taken from the world of art or the universe of everyday life, are considered suitable for direct integration into the work in progress.... ${ }^{36}$.

In Hejduk's work collage manifests itself in a composition focused on the analyticity of the constituent parts, as finished pieces immediately recognizable, and on their assemblage to fabricate the meaning of each Architecture/Mask.

\section{Masque as a factory of character: John Hejduk a builder of worlds}

The Oslo Mask of Security is not alone in appearing in tangible reality. Over time, other installations and architectures of the Masque have been realized in the world ${ }^{37}$ by citizen, architects, craftsmen, professors and students.

With these projects of small architectures realized as urban installations, the meaning and sense of the production of the Masques is largely explained: architectures as characters or characters as architectures that manifest the meanings and values of the city, telling the life of their inhabitants and their possible destiny.

The Masque Series is the factory of characters of Hejduk's idea of the city, the place where his imagination works to find the form of his time impelled by the desire for form.

This factory produces not only a typology of characters but its entire formal language, precisely because for Hejduk the problem of the character of the building is at the origin of the genesis of form, and the reason without the project does not even begin.

The operation of the Masque is to establish a number of characters in relation to the plot, and this is also the ultimate meaning of the reference to the mask: fixing these characters in representative forms means creating fixed types, just as in ancient theatre a maximum number of masks was fixed for each theatre genre. ${ }^{38}$

As Hejduk remembers: «The method of practicing can be completely independent thing. What I did is build a repertoire of, say 400 pieces or 400 characters, and I've done that far over 14 years. Now what's happening, is that in different places of the world, they are building each of these characters ${ }^{39}$.

\footnotetext{
${ }^{36}$ RYOUT, D. L'arte del ventesimo secolo. Protagonisti, temi, correnti. Torino: Einaudi, 2002. p.119

${ }^{37}$ The list of realized Masque installation: “ House for a Painter and House for a Musician”, IBA'84, Berlin, 1983; “ The coIlapse of time", AA Pavillon, London, 1986; “The Riga project”, Riga, 1987; “Security” Oslo, 1989; "House of the suicide and House of the mother of the suicide", Atlanta, 1991 - Praha, 1992 - New York, 2016, Praha, 2017; "The Tower of Cards, The Tower of Letters, The Joker's perch", City Marking S08, Groningen, 1990; "La Mascara de la Medusa", Buenos Aires, 1998;

${ }^{38}$ SINISI,S. INNAMORATI, I. Storia del Teatro. Lo spazio scenico dai greci alle avanguardie. Milano: Bruno Mondadori, 2003.p.12.

${ }^{39}$ Art.cit. HEJDUK, J., SHAPHIRO, D. Conversation between John Hejduk ... p.
} 
Hejduk's Masque has produced about 400 characters, 400 architectural prototypes ready to be fielded for the construction of the city on a case-by-case basis, waiting to be tested and recognised by society. We can say prototype projects because they make an idea of a building appearing for the first time, but also prototypes because their experimental value is destined to undergo specifications during their "realization" process.

During the passage from conception to representation, these first-types establish a formal relationship with their idea, which fixes the meaning of the work and thus allows it to accommodate the subsequent processes of characterization of form in its approach to reality as a construction, without losing its original ideal power.

As a demonstration of that, some of these characters and programs for the construction of a possible town find the opportunity to be experimented by building parts or pieces of cities in existing contexts.

The projects carried out in Berlin and Santiago de Compostela - the Kreuzberg Tower and Wings, the Gate House, the House of the Quadruplets, the Belvís Bothanical Tower and the Civic Center of Trisca - are five architectures designed by Hejduk for real occasions between 1980 and 2000, representing the evolution of these prototypes towards physical reality. (Fig.9)

In these built examples, the approach to reality has reinforced even more that idea of a theatre city, which uses the existing city with its voids and its permanence as a background to build specific atmospheres or conditions to inhabit the city.

His realized buildings are the proof of the creative power of an architect who investigates in depth the essence of architecture, to find the authentic forms of his own time, so that they are valid for all times.

From the top of his house in Riverdale, New York Bronx, in a small room 9x6 foot, John Hejduk through his Masques has designed a world of architectures representing an idea of society and city, fulfilling the mission of architecture as a discipline for the construction of the world, as his words remind us: "I cannot do a building without building a new repertoire of characters of stories of language and it's all parallel. It's not just building per se. It's building worlds» ${ }^{40}$.

${ }^{40} \mathrm{Ibid}$ 


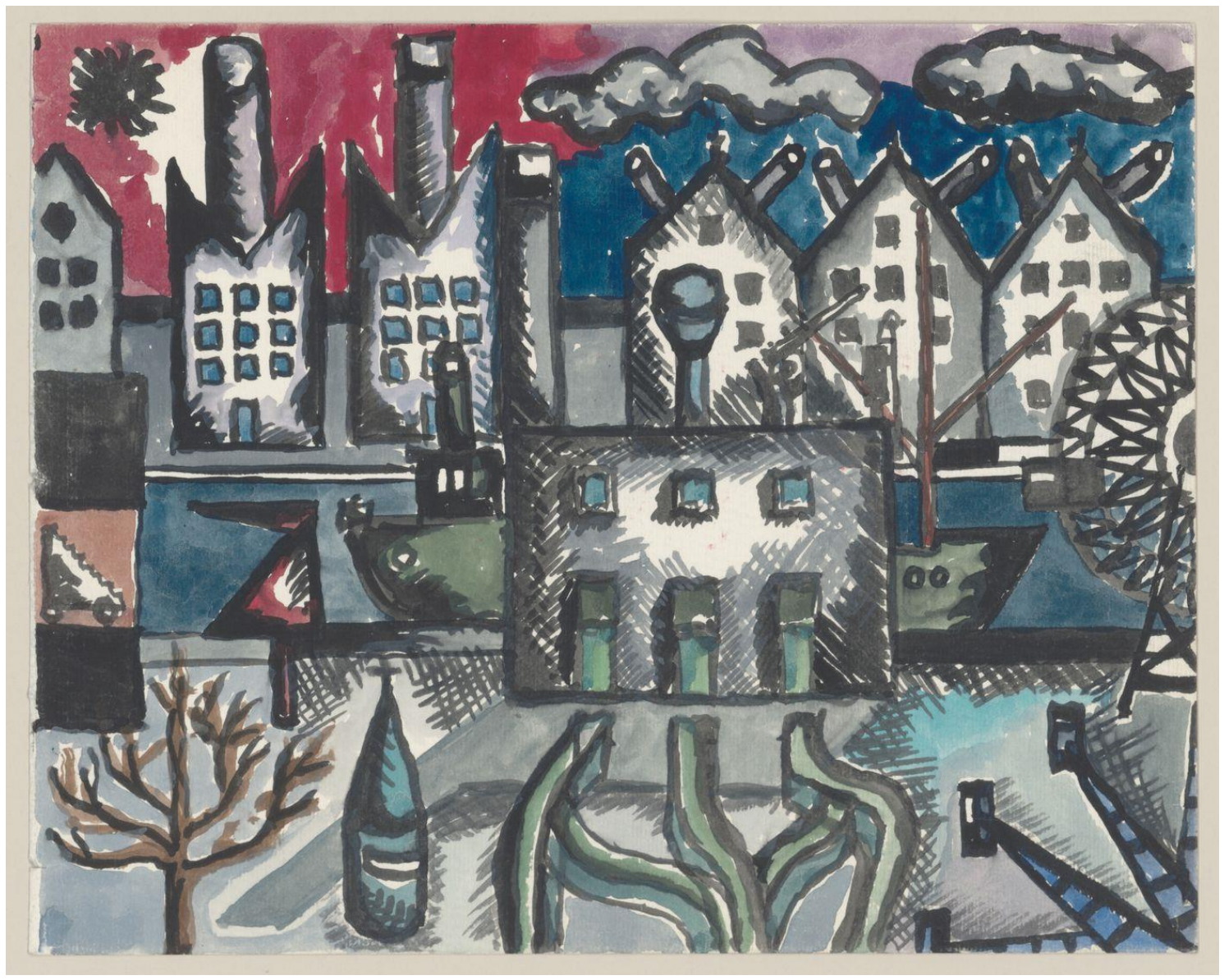

Fig. 1. John Hejduk, Riga, Artist's Book, 1985. (John Hejduk fonds, Collection Centre Canadien d'Architecture/ Canadian Centre for Architecture, Montréal. DR1998:0113:001) 

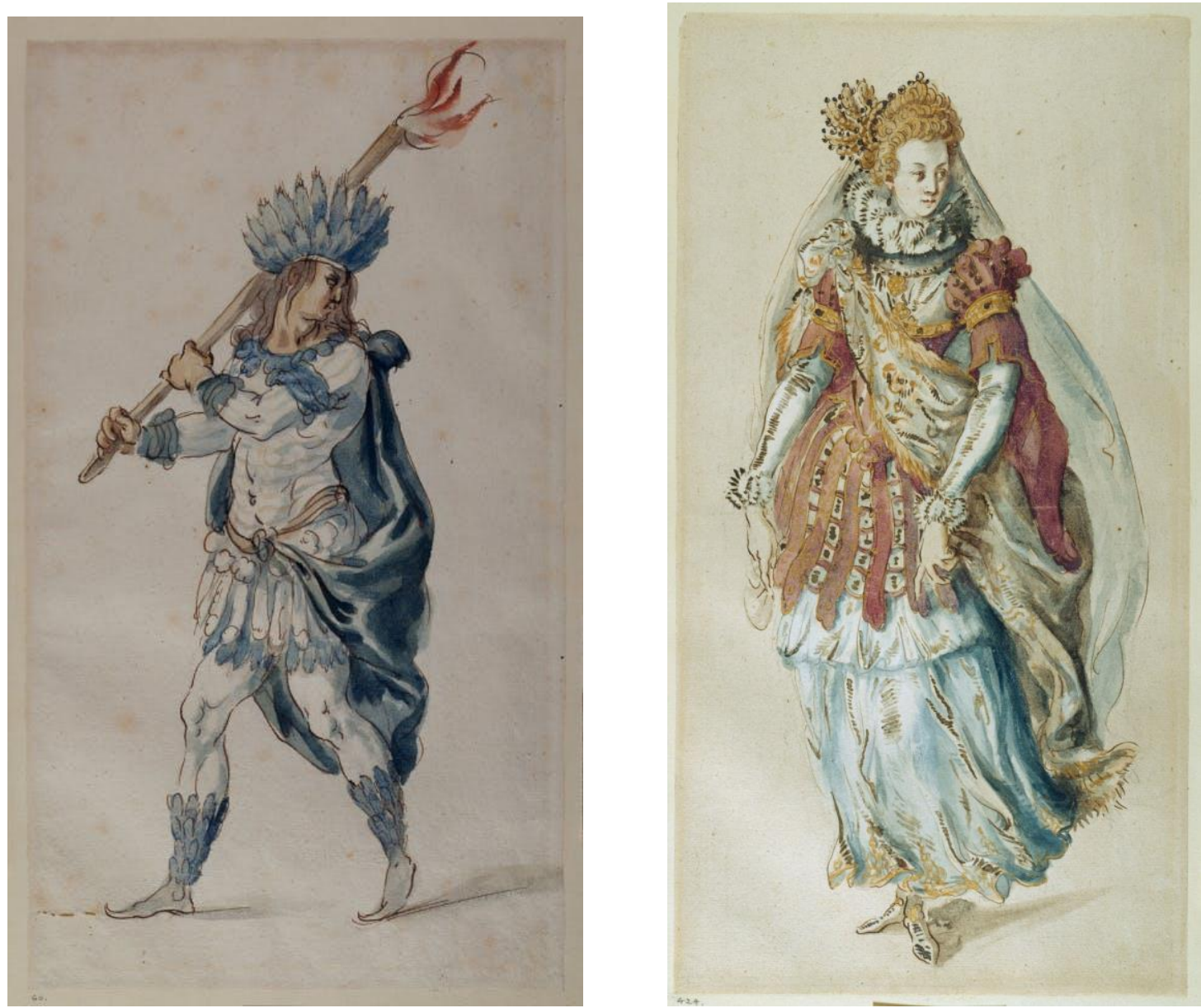

Fig. 2. 'A Torch Bearer, Indian' and 'A Statue Transformed', costume design for the masque by Inigo Jones , (C Chatsworth House 


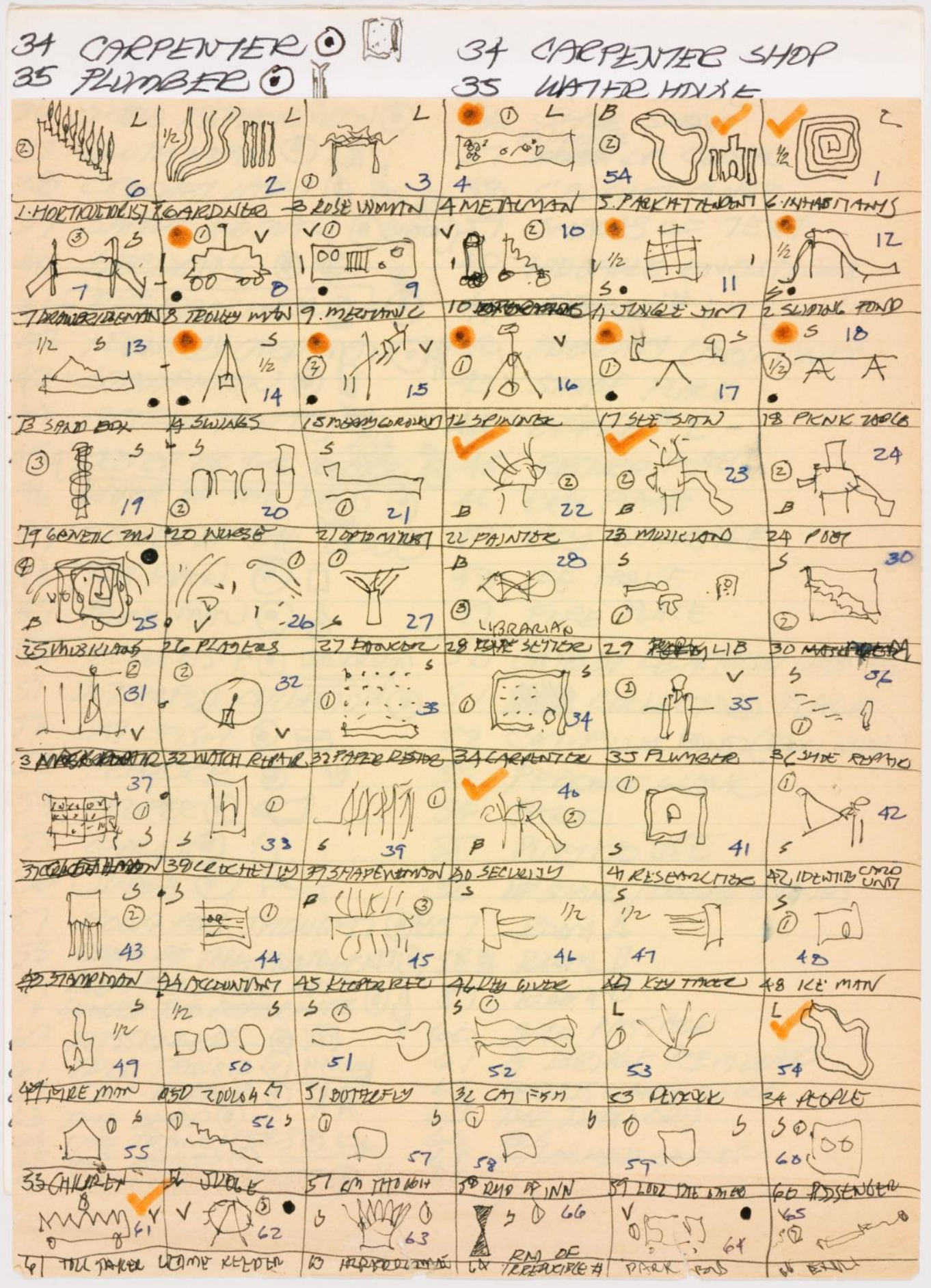

Fig. 3. John Hejduk Table and list of characters and structures for Victims I, 1984. (John Hejduk fonds, Collection Centre Canadien d'Architecture/Canadian Centre for Architecture, Montréal. DR1998:0109:002:002) 


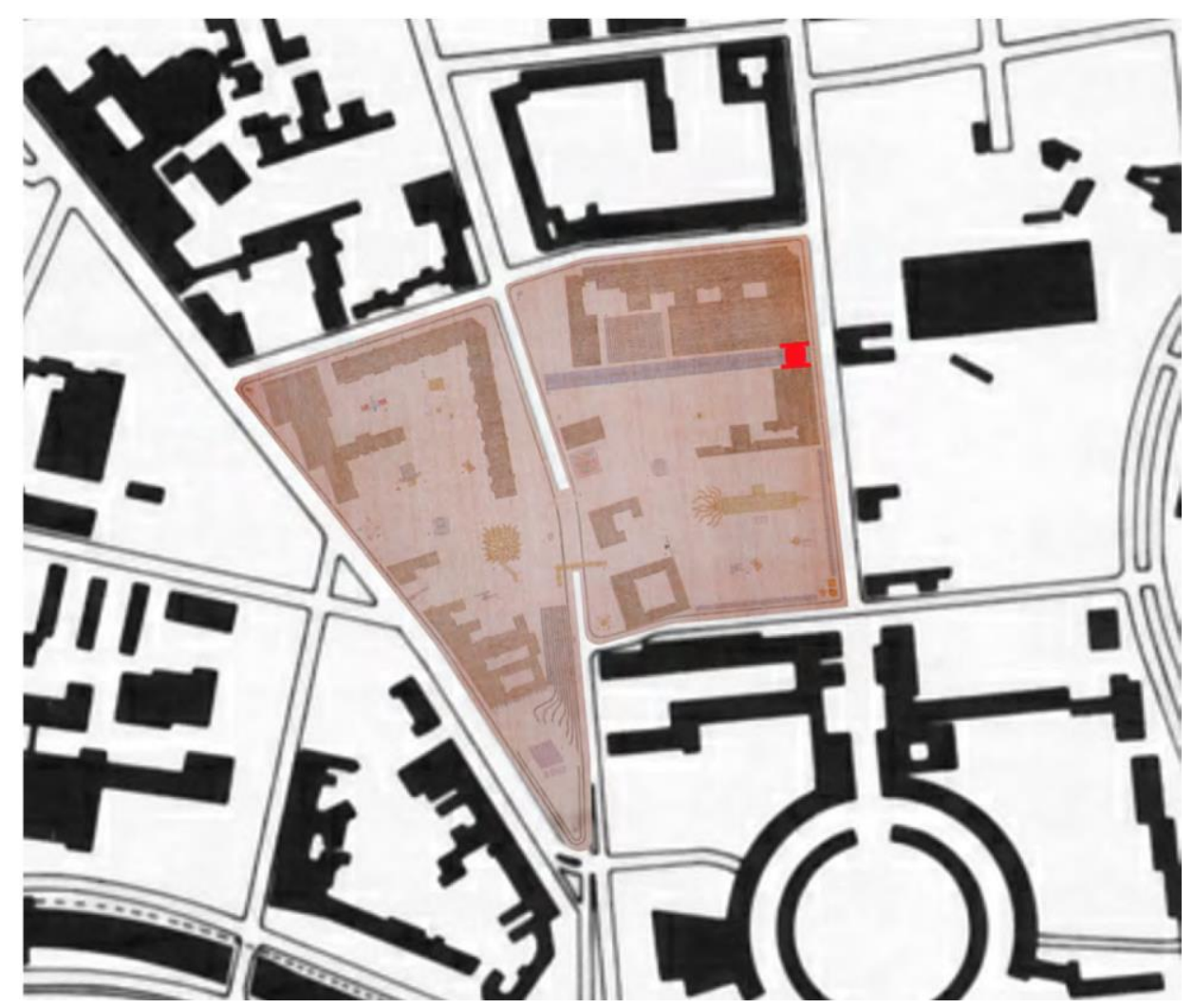

Fig .4 Collage of Berlin Masque by John Hejduk into the Schwartzplan of Berlin Friedrichstrasse in 1981. (Collage by the author)

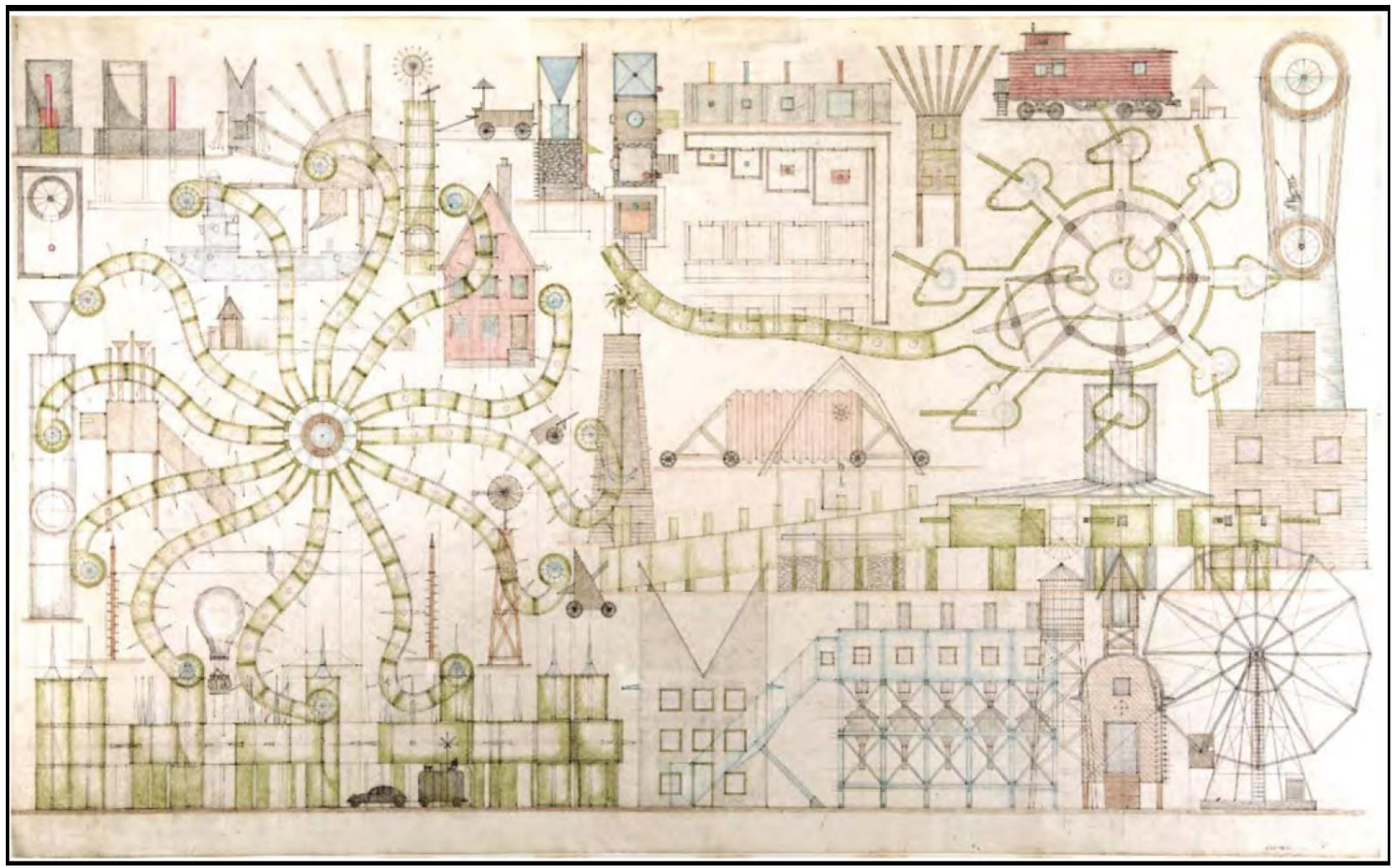

Fig. 5. John Hejduk, Presentation drawing for the Lancaster/Hanover Masque, Lancaster/Hanover Masque, 1980-1982. (John Hejduk fonds, Collection Centre Canadien d'Architecture/Canadian Centre for Architecture, Montréal. DR1988:0291:049) 


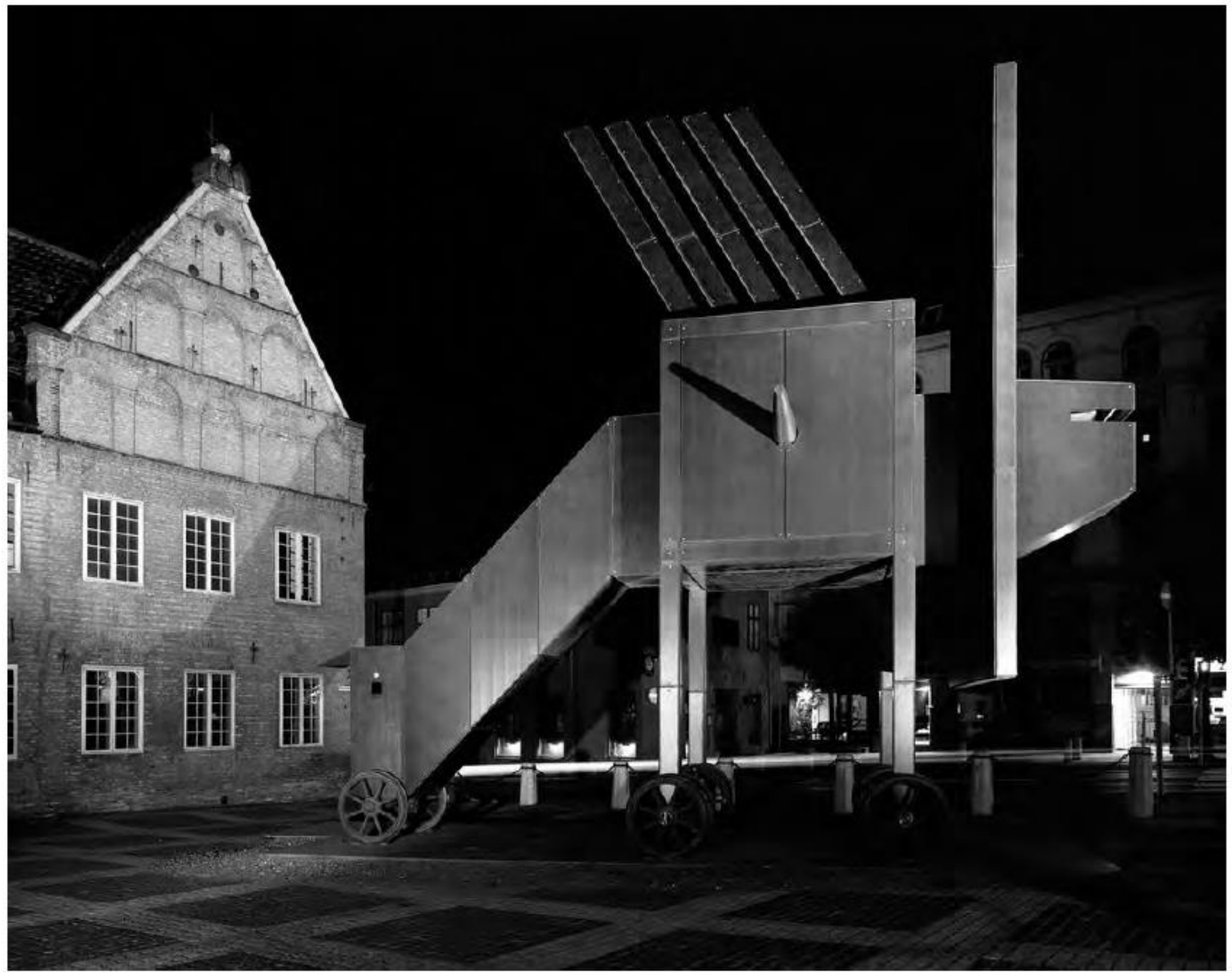

Fig. 6 John Hejduk, Security, Oslo, 1989. (Photo by Helene Binet) 

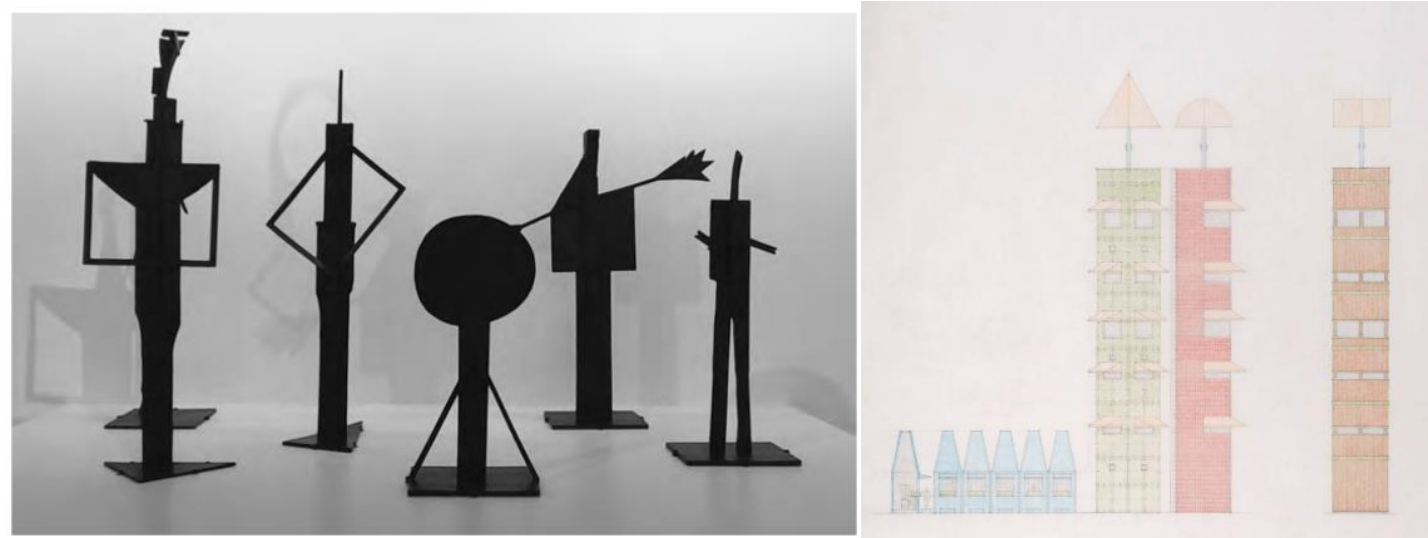

Fig. 7 Comparison: Picasso, Wodden Mask, 1928; John Hejduk, Berlin Masque, 1981.
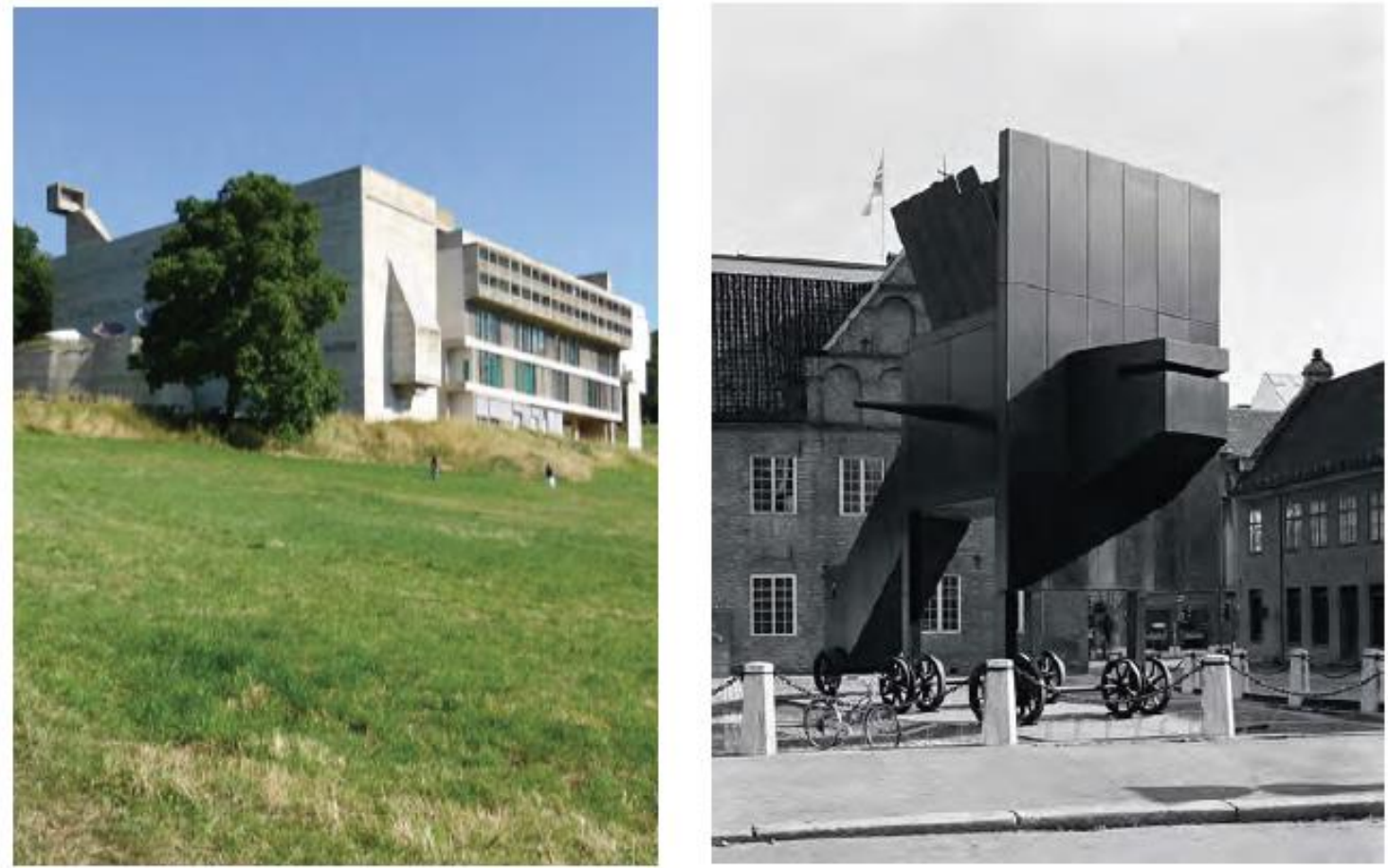

Fig. 8 Comparison: Le Corbusier, Sainte la Marie de La Tourette, 1956-60; John Hejduk, Security, Oslo, 1989. 

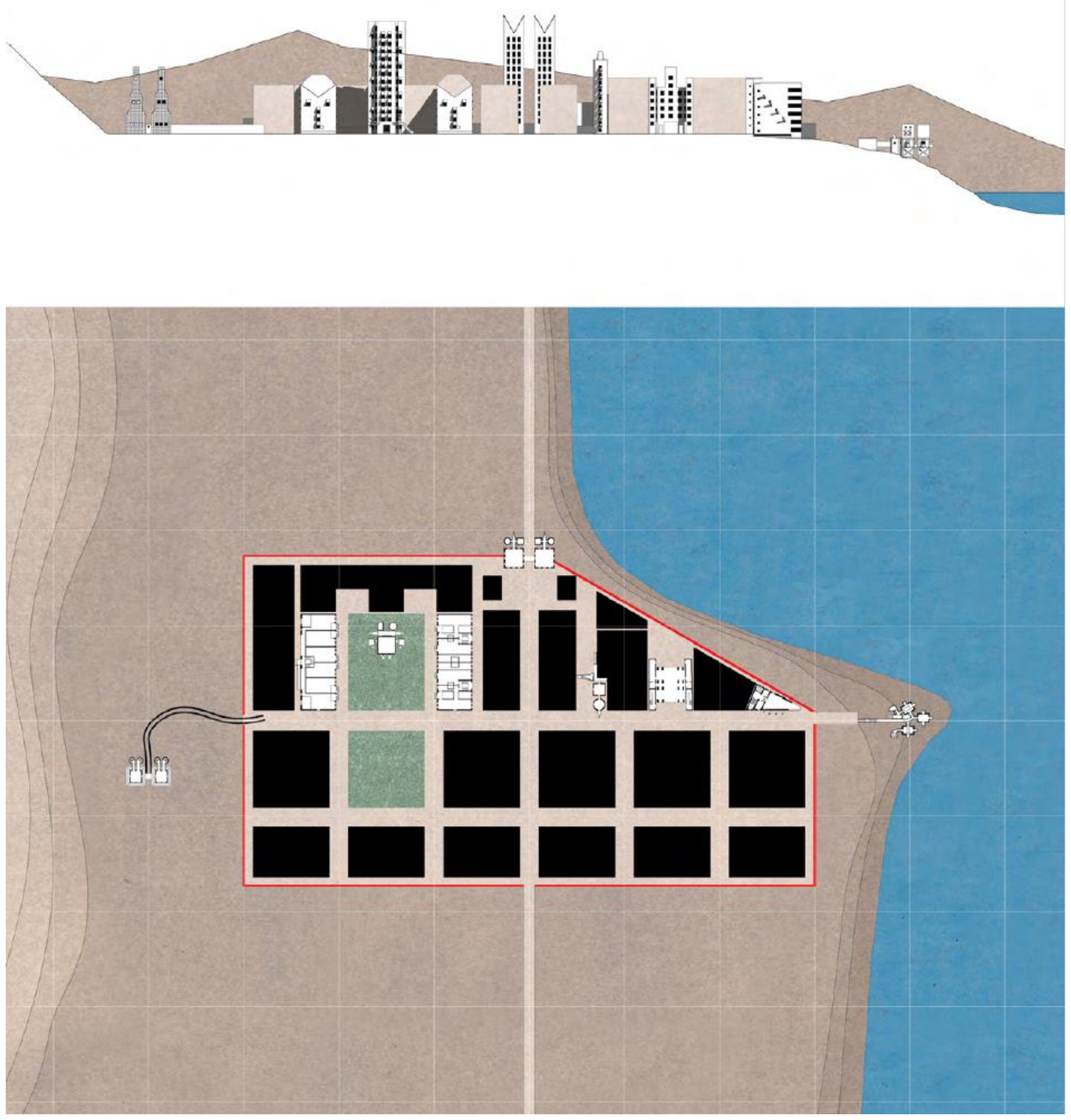

Fig. 9 Hejduk's city, Hypothetical urban composition with Hejduk's characters. (Drawings by Author) 


\section{Referencias}

BROCKETT, O.G. History of the Theatre. Boston: Allyn \& Bacon, 1968.

KAUFMANN, E. Tre architetti rivoluzionari. Boullée, Ledoux, Lequeu. Milano: Franco Angeli, 1976.

SCHULZE, F. (edited by). MASQUES, John Hejduk. Chicago: The Renaissance Society at The University of Chicago, 1981.

HEJDUK, J. with PALESTRI, G. Berlin Masque. Design fo Block 19, Südliche Friedrichstadt. En: Lotus International. 1981, no.33, pp.21-25.

HEJDUK, J. Mask of Medusa. Works 1947-1983. New York: Rizzoli, 1985.

HEJDUK, J. Bovisa. New York: Rizzoli, 1988.

VAN DEN BERGH, W. John Hejduk's Masques. In: Forum. 1988, May, no. 02, pp. 32-41.

THAU, C. An introduction to and a conversation with the american architect, who is now building in Berlin. In: SKALA, 1988, no.16.

HEJDUK, J. Riga, Vladivostok, Lake Baikal / a work by John Heiduk. Edited by di Kim Shkapich. New York: Rizzoli international, 1989.

HEJDUK, J., SHAPHIRO, D. Conversation between John Hejduk and David Shaphiro. En: $A+U, 01 / 1991$ $\mathrm{n}^{\circ} 244$.

VIDLER, A. The Architectural Uncanny. Essays in the Modern Unhomely. Cambridge - London: MIT, 1992.

HEJDUK, J. The Lancaster/Hanover Masque. London: Architectural Association, 1992.

CHI, L. "The problem with the Architect as Writer...” Time and Narrative in the work of Aldo Rossi and John Hejduk. In: PELLETIER, L. and PÉREZ - GÔMEZ, A. (edited by). Architecture, ethics and Technology. Montréal \& Kingston - London - Buffalo: McGill-Queen's University Press, 1994, pp.199-221.

CONRAD, M. THÅN, A. Security: a work by John Hejduk. Oslo: Aventura Forlag, 1995.

RIZZI, R. John Hejduk. Incarnatio. Venezia: Marsilio, 2010.

SEMERANI, L. Incontri e Lezioni. Attrazione e contrasto tra le forme. TECA 8 Teorie della Composizione Architettonica. Napoli: CLEAN, 2013.

CARDANI, L. John Hejduk. La fabbricazione del carattere. Ph.D Thesis:, IUAV University of Venice School of doctorate, Venezia, 2017 - XXIX, Supervisors: DAL FABBRO, A. GALLO, A. MONICA, L.

BARBERÁ PASTOR, C. From the Widow's Walk to Security: an Interpretation on the Masques of John Hejduk. In: Proyecto, Progreso, Arquitectura, n.19, Noviembre, 2018. p. 89.

CARDANI, L. John Hejduk vis-à-vis Aldo Rossi. In: Aldo Rossi, PERSPECTIVES FROM THE WORLD. Theory, Teaching, Design \& Legacy. BOVATI, M., CAJA, M., LANDSBERGE, M. LORENZI,A. (edited by). Padova: Il Poligrafo, 2020. 


\section{Bio}

Luca Cardani (Ph.D Architect). Graduated in Architecture in 2013 at Politecnico di Milano School of Architecture with a design thesis about the historical center of Urbino Italy. In 2017 he took a Ph.D. in Architectural Composition at IUAV University of Venice with a thesis entitled: "John Hejduk. The fabrication of character”. Adjunct Professor at Politecnico di Milano - School of Architecture, Urban Planning and Construction Engineering since 2018. He is post-doctoral fellow at Politecnico di Milano - Mantua Unesco Chair since 2018, following a research project for the enhancement of the historical heritage of Mantua. He takes part in various international competitions and research projects. He collaborates as an architect with Monestiroli Architetti Associati. 
